\title{
Estabelecendo pontos teóricos de convergência entre Projetos de Ensino-Aprendizagem e Tecnologias Digitais de Rede
}

\author{
Vitor Malaggi ${ }^{1}$, Adriano Canabarro Teixeira ${ }^{1,2}$, Juliano T. da Silva ${ }^{1}$ \\ ${ }^{1}$ Faculdade de Educação, Programa de Pós-Graduação em Educação \\ Universidade de Passo Fundo (UPF) - Passo Fundo - RS - Brasil \\ ${ }^{2}$ Instituto de Ciências Exatas e Geociências, Curso de Ciência da Computação \\ Universidade de Passo Fundo (UPF) - Passo Fundo - RS - Brasil \\ malaggi@gmail.com, \{teixeira, tonezer\}@upf.br
}

Resumo. Este artigo apresenta uma proposta teórica inicial de união entre duas temáticas de estudo concernentes aos campos da Educação e Informática: os Projetos de EnsinoAprendizagem e as Tecnologias Digitais de Rede. Através do estabelecimento de reflexões acerca de alguns pontos-chave, tais como a problemática do ensino-aprendizagem, os papéis/relação de professores e alunos, bem como a constituição curricular, pretende-se delimitar um sistema didático por Projetos que se utilize das características destas tecnologias na abertura de novas potencialidades para o processo educativo.

Palavras-chaves: projetos de ensino-aprendizagem, tecnologias digitais de rede, processo de ensino-aprendizagem, papéis/relação de professores e alunos, constituição curricular.

\section{Establishing theoretical convergence points between Teaching- Learning Project and Network Digital Technologies}

Abstract. This article presents an initial theoretical proposal of union between two study topics concerning the fields of Education and Informatics: the Teaching-Learning Projects and the Network Digital Technologies. Through the establishment of reflections about some key points, such as the problem of teaching-learning, the role/relationship of teachers and students, as well as the curriculum constitution, it intents to define a didactic system by Projects that use the characteristics of these technologies in the opening of new possibilities to the educational process.

Key-words: teaching-learning projects, network digital technologies, teaching-learning process, roles/relationship of teachers and students, curriculum constitution.

\section{Introdução}

O filósofo Immanuel Kant (1724-1804), um dos grandes pensadores Iluministas, escreveu em seu livro "Sobre a Pedagogia" que "[...] a educação é o maior e mais árduo problema que pode ser proposto aos homens". Pode-se dizer que este desafio é permanente e ainda hoje mais urgente. Séculos se passaram, e o modo como à instituição Escola ainda atua está arraigada em uma concepção de educação diretamente influenciada por uma idéia de sociedade que já não mais condiz com a realidade. Em seus processos formativoeducacionais, a escola vem desconsiderando em grande parte as transformações da sociedade e de seus condicionantes culturais e tecnológicos, os quais acabaram por re-configurar as 
complexas redes de relações existentes entre os diversos entes sociais, afetando desde o modo como estes se comunicam até a maneira como trabalham e produzem.

Assim, faz-se necessária, na área educacional, a abertura de novas perspectivas baseadas em um diálogo entre diversos campos do conhecimento, fomentando reflexões e propostas de ações que visem construir alternativas para que a educação possa corresponder aos desafios que lhes são propostos face à realidade social em que está inserida.

Considerando estas idéias iniciais, o objetivo principal deste artigo é o desenvolvimento de reflexões acerca de dois temas inseridos neste amplo contexto de debate: os Projetos de Ensino-Aprendizagem (PEA) e as Tecnologias Digitais de Rede (TDR). Através da busca de pontos de convergência entre os conceitos, metáforas e idéias destas duas temáticas, pretende-se delimitar um aporte teórico que possibilite utilizar as características e potencialidades das TDR para o estabelecimento de novos caminhos na efetivação do processo educativo através de PEA.

\section{Projetos de Ensino-Aprendizagem}

Em linhas gerais, os Projetos de Ensino-Aprendizagem (PEA) visam constituir um sistema didático que pretende pôr em prática um conjunto de idéias referentes ao modo como se efetua o processo educativo, partindo de um processo de reflexão e re-significação de alguns princípios postulados por autores como John Dewey (DEWEY, 1959), (LOURENÇO FILHO, 1978), Fernando Hernández (HERNÁNDEZ, 1998), e Léa da Cruz Fagundes (FAGUNDES; SATO; MAÇADA, 1999) sobre a utilização dos Projetos na Educação.

As bases históricas do uso dos Projetos na Educação advêm das reflexões educacionais efetuadas pelo movimento da Escola Nova, e, de maneira mais específica, pelas idéias de John Dewey (LOURENÇO FILHO, 1978). Porém, os PEA visam partir da análise e reflexão destas importantes contribuições, delimitando algumas re-interpretações sobre pontos pedagógicos do uso de Projetos na Educação, processo que acaba por propiciar pontos de vista diferenciados sobre determinadas questões deste contexto de estudo. Assim, o objetivo principal para os PEA é ressaltar a importância dos processos de ensino-aprendizagem realizados na escola e que tem papel fundamental na ascensão dos alunos a níveis cada vez maiores e mais qualificados de interação com o mundo, a cultura e os sujeitos sociais, promovendo as condições para o desenvolvimento cognitivo do aluno e a sua ascensão as formas mais elevadas de pensamento conceitual abstrato (VYGOTSKY, 1998), (VYGOTSKY, 1991). Neste contexto, a Teoria Histórico-Cultural provê um suporte para a reflexão dos papéis primordiais da internalização da cultura, via interação social, por meio de cooperação e colaboração, para a ocorrência dos processos de ensino-aprendizagem que acabam por influenciar todo o desenvolvimento psicológico do ser humano. (OLIVEIRA, 1997)

Uma primeira questão referente aos pontos-chave educacionais dos Projetos de Ensino-Aprendizagem diz respeito às relações redefinidas entre os dois sujeitos principais envolvidos no processo de ensino-aprendizagem escolar: o professor e o aluno. Assim, nos PEA estes dois papéis devem ser redefinidos nos seguintes termos: o aluno deve ser considerado um ser ativo na apropriação dos conhecimentos advindos da cultura organizada e que são ensinados na escola, o que pressupõe considerar o aprendiz capaz de realizar processos de análise, síntese, reflexão, interpretação e interligação dos conceitos advindos das disciplinas escolares, possibilitando uma apropriação original dos significados inerentes a estes conceitos. (VYGOTSKY, 1991, p.49), (REGO, 2005, p. 60). Ainda, os PEA postulam que o papel da intervenção pedagógica exercida pelo professor é um fator importante e essencial do processo formativo-educacional, visto que é através desta intervenção que os processos de ensino-aprendizagem irão acontecer, criando as condições para o surgimento da 
Zona de Desenvolvimento Proximal (ZDP), processo que por sua vez desencadeará o desenvolvimento psicológico nos alunos (VYGOTSKY, 1998, p. 95-101). Porém, essa intervenção não deve ser considerada uma mera transmissão de conceitos, valores e significados do professor para o aluno. Ao contrário disso, a intervenção serve para que seja estabelecido um ponto de discussão, de diálogo, de interação que acaba por proporcionar os elementos necessários para que o processo de ensino-aprendizagem ocorra.

Outra questão especificamente pedagógica que deve ser tratada nas construções teóricas dos Projetos de Ensino-Aprendizagem é a constituição do currículo, ou seja, de como serão tratadas as diferentes disciplinas e atividades que tem como função promover a aprendizagem dos alunos. Neste caso, os PEA têm como princípio a adoção de uma postura que visa defender a necessidade da interligação dos saberes, pois é através de um trabalho de cooperação entre diversas áreas do conhecimento que uma problematização pode ser compreendida em sua totalidade. (HERNÁNDEZ, 1998, p. 36-39). Assim, os PEA optam pela necessidade da interligação dos saberes, de processos de globalização que possibilitem uma quebra com a fragmentação excessiva e estéril das áreas do conhecimento humano expressos nas disciplinas. (SANTOMÉ, 1998, p. 73)

Conectadas diretamente com as reflexões acerca de como são tratadas as áreas do conhecimento no âmbito dos Projetos de Ensino-Aprendizagem estão as questões acerca da organização do espaço e do tempo escolar, ou seja, do modo de constituição dos ambientes de aprendizagem em que estarão sendo desenvolvidos os projetos ${ }^{2}$. Assim, os PEA optam por uma organização espaço-tempo horizontal, permanentemente negociada entre todos os envolvidos com os processos de ensino-aprendizagem escolares. Com base nisso, afirma-se que, na verdade, esta organização deve adaptar-se à natureza dos Projetos de EnsinoAprendizagem que estarão sendo desenvolvidos por alunos e professores. Nestes termos, uma organização homogeneizada e massificada dos espaços de aprendizagem por turmas seriadas, baseadas em uma hierarquização conectadas à defesa de um contato e progressão linear dos alunos com os conteúdos escolares, deve ser substituída por uma organização flexível e dinâmica, que leve em conta o fato de que em um currículo organizado por projetos a diversidade de interesses que dá origem aos projetos pressupõe a capacidade de apropriação diferenciada dos respectivos espaços e tempos (FAGUNDES; SATO; MAÇADA, 1999, p 19).

Por fim, concluindo a idéia de sistematização dos Projetos de Ensino-Aprendizagem, faz-se necessário delinear os aspectos práticos do processo de ensino-aprendizagem que se pretende desenvolver com este sistema didático. Em uma visão geral, o desenrolar de um PEA pode acontecer baseado em alguns momentos-chave: problematização, definição da rede de conceitos espontâneos, definição das indagações-guias, mapa dos possíveis, desenvolvimento, avaliação, conforme detalhado na Tabela 1.

Tabela 1 - Pontos essenciais no desenvolvimento de um PEA

\begin{tabular}{|l|l|}
\hline \multicolumn{1}{|c|}{ Momento-chave } & \multicolumn{1}{c|}{ Descrição } \\
\hline Problematização & $\begin{array}{l}\text { A problematização é um momento onde o diálogo e o debate entre professor e aluno } \\
\text { ocorrem de modo intenso, visto que estes dois sujeitos deverão negociar o que será } \\
\text { objeto de estudo, levando em consideração o interesse do aluno, por um lado, bem } \\
\text { como também a necessidade do professor de realizar um encaminhamento } \\
\text { pedagógico as proposições iniciais e mais gerais dos alunos. }\end{array}$ \\
\hline $\begin{array}{l}\text { Definição da rede de } \\
\text { conceitos } \\
\text { espontâneos }\end{array}$ & $\begin{array}{l}\text { Os alunos deverão realizar um levantamento prévio do que já sabem sobre a } \\
\text { problematização proposta, ou seja, deverão relacionar a rede de conceitos } \\
\text { espontâneos que possuem, em diversas áreas do conhecimento, e que julgam estar } \\
\text { relacionada a esta problematização. }\end{array}$ \\
\hline $\begin{array}{l}\text { Definição } \\
\text { indagações-guias das }\end{array}$ & $\begin{array}{l}\text { Definição de um conjunto dúvidas e questionamentos que partam do problema geral } \\
\text { proposto e que, baseando-se na rede de conceitos espontâneos do aluno, juntamente } \\
\text { com um diálogo e negociação com o professor, permita ao discente analisar e } \\
\text { refletir, mesmo que inicialmente de maneira caótica, sobre possíveis conhecimentos }\end{array}$ \\
\hline
\end{tabular}




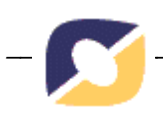

\begin{tabular}{|c|c|}
\hline & $\begin{array}{l}\text { que julgue necessário de serem estudados para que a problematização possa ser } \\
\text { resolvida. }\end{array}$ \\
\hline Mapa dos possíveis & $\begin{array}{l}\text { O professor, com base nos levantamentos dos conhecimentos prévios dos alunos e } \\
\text { das suas indagações deverá sistematizar, mesmo que inicialmente de maneira } \\
\text { precária, as possíveis áreas do conhecimento e, dentro destas, os conceitos e } \\
\text { categorias em específicos que potencialmente podem ser referenciados e necessários } \\
\text { à execução de um determinado projeto. }\end{array}$ \\
\hline \multirow[t]{2}{*}{ Desenvolvimento } & $\begin{array}{l}\text { Aluno: através da sua atividade cognitiva de analisar, compreender e interligar as } \\
\text { informações baseada na colaboração e co-autoria com professores e colegas, vai se } \\
\text { apropriando e estabelecendo relações entre os conhecimentos. Assim, o aluno } \\
\text { deverá ascender cada vez mais aos conceitos científicos estabelecidos pelas áreas do } \\
\text { conhecimento envolvidas na problematização, em um movimento de aproximação } \\
\text { progressiva destes conceitos com a sua rede de conceitos espontâneos advindos da } \\
\text { experiência concreta. }\end{array}$ \\
\hline & $\begin{array}{l}\text { Professor: poderá atuar como um especialista em sua área de conhecimento, } \\
\text { intervindo nos processos de ensino-aprendizagem, e, conseqüentemente, na ZDP dos } \\
\text { alunos. Deverá também em alguns momentos articular as aprendizagens dos alunos } \\
\text { com os objetivos e demandas propostas pelos projetos, bem como poderá ser um } \\
\text { orientador/tutor de um grupo de alunos em específico, podendo assim acompanhar e } \\
\text { analisar as aprendizagens que cada sujeito deste grupo está a realizar, bem como as } \\
\text { suas dificuldades e necessidades. }\end{array}$ \\
\hline $\begin{array}{l}\text { Socialização } \\
\text { avaliação }\end{array}$ & $\begin{array}{l}\text { A socialização e avaliação formativa devem ser realizadas durante todo o percurso } \\
\text { de um PEA, não como uma maneira de controlar, qualificar ou classificar, mas sim } \\
\text { para reorientar o processo de ensino-aprendizagem quando preciso, para que este } \\
\text { caminhe cada vez mais em direção a apropriação dos conhecimentos. Também pode } \\
\text { ser realizado um processo de avaliação final ou recapitulativa através da socialização } \\
\text { das sistematizações gerais efetuadas no PEA. }\end{array}$ \\
\hline
\end{tabular}

Fontes: (HERNÁNDEZ, 1998), (SMOLKA E DE LAPLANE, 2005, p. 83), (FAGUNDES, SATO E MAÇADA, 1999, p. 20-23), (LUCKESI, 2005, p. 84-101)

Por fim, destaca-se que estes momentos não devem ser realizados como uma sequiência rígida e linear de passos, mas deve-se sim adaptá-los as demandas específicas emanada de cada PEA desenvolvido pelo grupo de alunos. Assim, alguns destes momentoschaves, por exemplo, poderão ser referenciados diversas vezes durante o desenvolvimento de um PEA, o que acaba por quebrar com a lógica hierárquica e excessivamente metodológica que, por vezes, é adotada no contexto da aplicação de sistemas didáticos.

\section{Tecnologias Digitais de Rede}

Todo o debate acerca das modalidades tecnológicas denominadas neste artigo de "Tecnologias Digitais de Rede" deve ser inicialmente pautado por um processo de reflexão sobre o contexto da sociedade contemporânea, marcada por uma nítida inter-relação entre sociedade-cultura e os seus artefatos tecnológicos. É desta conjuntura sócio-cultural que emergem novas formas de sociabilidade e de práticas comunicacionais, novas formas de ser e estar no espaço e no tempo, e, conseqüentemente, de possibilidades de interação entre os seres humanos.

Deste contexto de imbricação entre cultura-sociedade contemporânea e tecnologias telemáticas emerge a cibercultura, conceito que segundo Lemos caracteriza "[...] a forma sociocultural que emerge da relação simbiótica entre a sociedade, a cultura e as novas tecnologias de base micro-eletrônica que surgiram com a convergência das telecomunicações com a informática na década de 70". (2003, p. 11) A partir das relações estabelecidas entre os sujeitos da sociedade contemporânea, mediatizadas pelas tecnologias telemáticas, surge um universo virtual que se alastra paralelamente ao universo físico, e que tem sua matriz calcada na interconexão mundial de computadores em rede: o ciberespaço. Assim, o ciberespaço se configura como um novo espaço para o estabelecimento de processos comunicacionais e de 
trocas de informações, sendo que todos estes processos operam neste mundo virtual, sustentado por redes de computadores que trabalham com informações digitalizadas, e que possuem a capacidade de interconectar homens e máquinas em relações multidirecionais. (LÉVY, 1999, p. 17)

Para que uma melhor compreensão do ciberespaço seja possível, torna-se necessário refletir sobre a linguagem operacional que molda e caracteriza este espaço-tempo de fluxos informacionais que emerge com os movimentos sociais de apropriação das tecnologias que configuram a cibercultura. Para desvelar a essência desta linguagem, três conceitos devem ser destacados neste processo reflexivo: hipertexto, hipermídia e a lógica das redes. O hipertexto pode ser designado como "[...] a apresentação de informações através de uma rede de nós interconectados por links que pode ser navegada livremente pelo leitor de um modo nãolinear". (RAMAL, 2002, p. 87) As compreensões das dinâmicas inerentes ao conceito de hipertexto apóiam-se ainda nas sistematizações de Lévy (1993, p. 25-26), que caracteriza através de seis princípios abstratos a lógica inerente a organização e constituição das redes hipertextuais: Princípio da metamorfose, Princípio da heterogeneidade, Princípio da multiplicidade e de encaixe das escalas, Princípio da Exterioridade, Principio da Topologia, Princípio da mobilidade dos centros.

Ainda neste contexto de debates, deve-se relatar que, cada vez mais, a disposição de informações no ciberespaço através da lógica hipertextual vem ocorrendo de maneira a integrar formatos midiáticos híbridos, ou seja, não só textos, mas também sons, imagens, vídeos, animações. Assim, tem-se o conceito de hipermídia, que sintetiza a idéia de um hipertexto multimídia, compreendendo '[...] uma forma 'tridimensional' combinatória, permutacional e interativa de multimídia, onde textos, sons e imagens (estáticas ou em movimento) estão ligados entre si por elos probabilísticos e móveis, que podem ser configurados pelos receptores de diferentes maneiras, de modo a compor obras instáveis em quantidades infinitas. (Machado apud Silva, 2002, p. 149) Nestes termos, a hipermídia agrega e sistematiza, conjuntamente com as dinâmicas e lógicas do hipertexto levantadas por Lévy (1993), um conjunto de características essenciais para compreensão da linguagem que torna operacional o ciberespaço: a hibridização de mídias, organização reticular de fluxos informacionais em arquiteturas hipertextuais, interatividade, entre outros. (SANTAELLA, 2004), (SILVA, 2002)

Por fim, tem-se a lógica das redes, essencial para compreensão dos processos multidirecionais/interativos de comunicação e disposição das informações que operam no âmago da linguagem hipermidial que formata o ciberespaço. Nestes termos, uma compreensão do conceito de rede pode partir das reflexões de Teixeira (2005), sendo que através destas, o autor visa desvelar as relações inerentes entre a lógica das redes e os fenômenos da cibercultura expressos por Lemos (2003) e as compreensões acerca dos processos hipertextuais proposta por Lévy (1993). Assim, Teixeira (2005, p. 24) define rede como uma

[...] estrutura dinâmica e aberta, cuja condição primeira de existência é a ação dos nós que a formam e que, ao construírem suas próprias formas de apropriação e de ação sobre a trama, modificam-na e por ela são modificados. Sua função básica é dar suporte ao estabelecimento de relações comunicacionais e colaborativas entre seus nós, entendidos como qualquer elemento que possa integrá-la num determinado momento a fim de completar algum significado ou sentido no processo corrente, independentemente de pertencer anteriormente ao emaranhado comunicacional.

Nestes termos, pode- afirmar o que está em jogo quando se ressalta as redes como lógica dos processos comunicacionais-informacionais: é a necessidade de que cada pessoa imersa no contexto tecnológico-cultural contemporâneo possa assumir-se como um nó da 
trama reticular, ou seja, reconheça-se como autor de sentidos, informações, idéias. A lógica das redes requer, invariavelmente, uma ruptura com a passividade característica dos meios de comunicação de massa (TV, rádio, jornal), que operam em uma lógica de distribuição de informações e entendimentos sobre a realidade nos moldes de um-para-todos, e, assim, cada integrante da sociedade contemporânea é chamado à atividade, a ser um produtor de informações, e não somente um mero receptor.

Partindo desta compreensão inicial, é importante verificar que os termos utilizados comumente para denominar as tecnologias surgidas da imbricação da informática com o ramo das telecomunicações, e do seu relacionamento com a cultura e a sociedade contemporâneas, tais como Tecnologias da Informação e Comunicação (TIC) e Novas Tecnologias da Informação e Comunicação (NTIC), serão substituídos neste artigo pela terminologia denominada de Tecnologias Digitais de Rede (TDR's). Apoiando-se nas observações efetuadas por Teixeira (2005, p. 32), justifica-se esta opção pelo fato de que, embora a terminologia TIC/NTIC compreenda o uso dos termos de comunicação conjuntamente com o de informação, a sua utilização tem sido freqüentemente banalizada ${ }^{3}$ e aplicada de maneira maciça para designar a captação, transmissão e distribuição de informações ${ }^{4}$. É neste contexto que se pretende conceituar a acepção "Tecnologias Digitais de Rede", com vistas a demarcar claramente as características que fazem com que estas tecnologias se apropriem de um paradigma de comunicação inerente à lógica das redes (CASTELLS, 1999, p. 488-499), bem como do caráter da digitalização da informação como base técnica que permite a criação do espaço do ciberespaço (LÉVY, 1999, p. 31-75).

Assim, as Tecnologias Digitais de Rede podem ser compreendidas, em um sentido amplo, como os suportes tecnológicos digitais dos ambientes hipermidiais de comunicação interativa, multidirecional e rizomática que surgem com o advento da cibercultura e do ciberespaço. Neste sentido, as TDR's permitem o estabelecimento de processos de autoria colaborativa e protagonismo para cada nó pertencente a uma determinada rede sociotécnica, engendrando, assim, a inteligência coletiva que sintetiza a idéia do movimento social de apropriação crítica e criativa destas tecnologias na cibercultura. (LÉVY, 2003) Portanto, é com base neste conceito de TDR's que se torna possível compreender a explosão de pontos de troca de informações, de possibilidades para a efetivação de processos comunicativos multidirecionais e interativos entre os seres sociais pertencentes a sociedade contemporânea atrelada a cibercultura. Este contexto sócio-cultural-tecnológico fica explícito através dos movimentos de criação e apropriação social de TDR's como o e-mail, chat, fórum, grupo e lista de discussão, ambientes de autoria colaborativa (Wiki's, Google Docs), programas de comunicação instantânea (Microsoft MSN, Kopete, aMSN), Blogs e Fotologs, ambientes virtuais tridimensionais que permitem o estabelecimento de redes sociais (Second Life), sites de relacionamento e de criação de comunidades virtuais (Orkut), entre tantos outros que surgem constantemente.

Levando em conta todo o estudo efetuado até então, a problemática a ser posta neste contexto de estudos é: quais são as possibilidades educacionais abertas através da apropriação das TDR's com vistas a potencializar os pressupostos dos Projetos de Ensino-Aprendizagem? Com base neste problema, é possível iniciar o estabelecimento teórico da união interdisciplinar entre pontos pedagógicos dos PEA que possuam uma convergência educacional com conceitos, metáforas e idéias referenciados no estudo das TDR's.

\section{Imbricando Projetos de Ensino-Aprendizagem e Tecnologias Digitais de Rede: busca de novas re-significações e potencialidades}

Com base em todo o estudo efetuado sobre os PEA's e as TDR's, o objetivo principal do presente artigo dirige-se neste momento para o estabelecimento de um processo reflexivo 
visando a imbricação de questões teórico-conceitual destas temáticas. Para isso, serão delimitados três pontos-chaves de discussão-convergência: os processos de ensinoaprendizagem, os papéis/relacionamento de professores e alunos, e a constituição do currículo escolar.

No que se refere ao entendimento acerca dos processos de ensino-aprendizagem desenvolvidos na escola, é necessário relembrar que a base teórica da Teoria HistóricoCultural de Vygotsky provê um conjunto de conceitos que expressam como os PEA compreendem a emergência e o transcorrer destes processos. Assim, a apropriação das TDR's em um ambiente educacional embasado nos pressupostos dos PEA encontra um contexto profícuo para abertura de possibilidades nos processos de ensino-aprendizagem, visto que as suas características, advindas da hipermídia como linguagem para o estabelecimento de comunicações baseada na lógica reticular e hipertextual, provê meios para que processos de autoria colaborativa, de partilha de saberes e de criação de coletivos inteligentes no ciberespaço possam potencializar este ambiente educacional. Nestes termos, Lévy aponta que a "[...] direção mais promissora, que por sinal traduz a perspectiva da inteligência coletiva no domínio educativo, é a da aprendizagem cooperativa". (1999, p. 171, grifo do autor) Através do uso destas tecnologias, alunos e professores podem expandir as fronteiras dos processos de ensino-aprendizagem para além dos muros da escola, entrando em um espiral de interação social com sujeitos espalhados pelo mundo.

Ainda, sobre a questão da união, PEA e TDR's, é possível refletir sobre a constituição de uma relação professor-aluno nos PEA fundada na lógica das redes e nos princípios do hipertexto. Assim, propõe-se a criação de redes de ensino-aprendizagem, tomando para isso o aporte das TDR's com o objetivo de apropriar-se de todo o seu potencial para o estabelecimento de processos interativos, onde, além de professores e alunos, a rede estabelecida poderá ser ocupada por instituições, outros sujeitos espalhados pelo mundo, idéias, teorias, baseando-se assim no Princípio da Heterogeneidade proposto como caracterização do hipertexto por Lévy (1993). Nestes termos, Serpa (2004, p. 173), propõe a necessidade constante de negociações envolvendo professores $\mathrm{e}$ alunos para $\mathrm{o}$ desenvolvimento de uma pedagogia relacionada com as TDR's.

Seguindo este processo reflexivo, outros princípios do hipertexto postulados por Lévy (1993) oferecem um conjunto conceitual útil para propor a re-significação das relações entre professor-aluno e demais sujeitos possíveis de serem envolvidos em um processo de ensinoaprendizagem baseado nos pressupostos dos PEA e nas características das TDR's. Nestes termos, o Princípio da Metamorfose pode ser apropriado para explicitar o caráter altamente dinâmico do movimento dos nós e as suas inter-relações estabelecidas na rede de ensinoaprendizagem. As mudanças constantes pelas quais a rede de ensino-aprendizagem passa ao ser estabelecido um processo de utilização dos PEA com o aporte das TDR's, bem como os processos de (re)negociação que buscam equilibrar as relações em seu interior, colocam em evidência a metamorfose da estrutura reticular segundo as necessidades que vão surgindo.

Outro princípio postulado por Lévy (1993), o da Multiplicidade e de Encaixe de Escalas, ajuda na compreensão de como a rede de ensino-aprendizagem estabelecida não se torna finita e circundada apenas pelos nós visíveis em um determinado espaço de aprendizagem. Assim, se analisarmos que cada sujeito, instituição, idéia e teorias podem se constituir em um nó da rede, e que, além disso, cada um desses nós pode ser um possível conector para o acesso a uma outra rede, e essa mesma rede pode dar acesso a outra rede que possui elementos em comum e importantes para o processo de ensino-aprendizagem estabelecido, as possibilidades abertas para a expansão do conhecimento, das comunicações e acesso as informações, fatos, idéias tendem ao infinito, ou, ao menos, a toda extensão e interatividade proporcionada pela apropriação das TDR's. 
Nestes termos, os modelos rígidos e lineares de organização do espaço e do tempo escolar através de séries, turnos, turmas e salas de aulas estanques não têm mais razão de existir, visto que, no estabelecimento de uma rede de ensino-aprendizagem, a possibilidade que alguma idéia, pessoa ou instituição seja referenciada e incorporada no processo por meio do acesso a redes de níveis com crescente precisão, não obedece a uma demanda ou ordem passível de ser previamente programada, ou hierarquizada por professores ou gestores de educação. Através da apropriação das TDR's, os diversos sujeitos envolvidos nos processos de ensino-aprendizagem estabelecidos nos PEA poderão constituir coletivos inteligentes no ciberespaço, criar redes de relações e cooperação com nós possíveis de serem integrados à rede, os quais podem estar espalhados pelo mundo, utilizando assim todo o potencial aberto por estas tecnologias para favorecer a autoria colaborativa, o protagonismo criativo e crítico, a partilha dos saberes.

Assim, o ambiente que emana quando se estabelece rede de ensino-aprendizagem através dos pressupostos educacionais dos PEA e das características das TDR's necessita, invariavelmente, de uma nova postura de professores e alunos enquanto sujeitos do processo de ensino-aprendizagem.

Recorrendo ao conceito de interatividade através da reflexão proposta por Silva (2002), uma primeira questão a ser pontuada é que o professor, entendido na tradicionalmente como um emissor de verdades, de informações, conceitos e valores a serem memorizados pelos alunos, perde o seu sentido de existência. Do mesmo modo, um professor passivo, que baseia sua atividade pedagógica no "deixar fazer" do aluno, em seu espontaneísmo e livre atividade, também não está em correspondência com os preceitos da interatividade. De outro lado, o receptor, ou seja, a compreensão clássica do aluno, como sujeito que recebe passivamente as informações repassadas do professor, deixa de existir em um ambiente educacional permeado pela perspectiva da interatividade. Assim, pela atividade de cooperação que se estabelece entre professores e alunos, ou seja, através dos papéis de emissão e recepção re-significados segundo os pressupostos da interatividade, o ensino-aprendizagem vai ocorrendo via processos que considerem o caráter coletivo e de partilha de conhecimentos, o que no âmbito dos PEA é corroborado pela compreensão vygotskyana do fenômeno educacional.

Nestes termos, no contexto de união entre PEA's e TDR's existe uma necessidade inerente do aluno se tornar um nó ativo/participativo das redes de ensino-aprendizagem que se articulam. A lógica das redes exige que cada nó da malha reticular, com base em processos essencialmente interativos, seja protagonista e atue no âmago das relações e atividades que se desencadeiam na rede, pois a atividade dos nós é pressuposto para a existência na, e da, rede. Nestes termos, a Teoria Histórico-Cultural de Vygotsky, ao tratar dos processos de apropriação da cultura coloca que, ao estabelecer um processo de internalização dos significados culturais por meio da interação social, o sujeito nunca age de maneira passiva, absorvendo estes significados sem operar sobre estes alguma transformação, mas sim desenvolve a definição de um sentido para este significado que lhe é próprio. (PINO, 2005, p. 19). Já no que se refere a papel do professor, este vem a ser reconhecido como essencialmente necessário, na condição de mediador essencial do processo de ensino-aprendizagem. Nas palavras de Silva e Claro (2007, p. 83), o professor atuando com base nos pressupostos da interatividade e de Vygotsky torna-se "[...] o agente mediador do processo de aprendizagem e, com suas intervenções e provocações, contribui decisivamente para o fortalecimento de funções ainda não consolidadas, ou para a abertura de zonas de desenvolvimento proximal".

Conforme o que foi discutido até então sobre o papel do professor re-significado no ambiente de apropriação das TDR's e suas características pelos PEA, acrescenta-se a breve citação de dois termos criados por Silva (2002) e Ramal (2002) que expressam as funções e a natureza do trabalho a ser desenvolvido pelos docentes, respectivamente: o professor como 
designer pedagógico e como dinamizador da inteligência coletiva. Na primeira concepção levantada por Silva (2002), o professor o professor tem como função-chave disponibilizar os conteúdos de ensino-aprendizagem (idéias, teorias, conceitos) em espaços de participação e construção coletiva de saberes, cuidando para que a materialidade da ação educacional interativa ocorra através da co-autoria que os alunos estabelecem a partir dos múltiplos percursos que o professor planeja em forma de redes de ensino-aprendizagem potenciais. (SILVA, 2002, p. 73) Outro conceito refere-se ao professor como um dinamizador da inteligência coletiva e que, no âmbito da proposta de união dos pressupostos educacionais dos PEA com as características advindas das TDR's, compõem um elo entre a re-significação do papel do docente e a forma como os processos de ensino-aprendizagem são compreendidos neste contexto. Nestes termos, segundo Ramal o professor atuando neste papel se caracteriza por ser:

(a) responsável pelo gerenciamento de processos de construção cooperativa do saber, (b) transformando grupos escolares heterogêneos em comunidades inteligentes, flexíveis, autônomas e felizes, (c) integrando as múltiplas competências dos estudantes com base em diagnósticos permanentes, (d) convidando ao diálogo interdisciplinar e intercultural nas pesquisas realizadas, (e) promovendo a abertura dos espaços e dos tempos de aprendizagem para além da sala de aula e estimulando a comunicação interpessoal por meio da pluralidade de linguagens e expressões. (2002, p. 206-227)

Por fim, a questão curricular é de grande importância no âmbito dos pressupostos educacionais dos PEA: de um lado, tem-se a necessidade de romper com o paradigma de fragmentação dos saberes em diversos nichos de conhecimentos específicos que não se comunicam entre si, bem como a idéia de artificializar o conhecimento a ser transmitido aos alunos em sala de aula, ou seja, distanciar estes da vida do aluno, da realidade. Do outro lado deve-se efetivar uma crítica a posições educacionais que caracterizaram uma posição de desprezo aos conhecimentos sistematizados e a sua apropriação pelos alunos, reconhecendo que o fim educacional maior atribuído a escola seria o "aprender a aprender", ou seja, desenvolver no aluno competências para que este seja capaz de se apropriar de algum conhecimento quando for necessário, como nos referenciais da Escola Nova.

Assim, é possível defender que os PEA encontram-se na questão curricular em consonância com as idéias e características que estão subjacentes a apropriação das TDR's em um ambiente educacional. Como afirma Ramal (2002, p. 185), o movimento contemporâneo das TDR's, que incorporam os princípios do hipertexto e da lógica das redes, em sua gênese "[...] provoca a escola, com sua organização fragmentada dos saberes, com seus currículos seqüenciais e pseudo-lineares, que pressupõem etapas a serem vencidas, pré-requisitos que funcionam como degraus". Com base nesta colocação, uma idéia levantada por esta autora a cerca da organização curricular advém da concepção de currículo em rede, ou seja, um currículo que esteja de acordo com as características do hipertexto e da lógica das redes. Portanto, esta forma de organização curricular seguiria os seguintes pressupostos: a) Metamorfose; b) Mobilidade dos Centros; c) Interconexão; d) Exterioridade; e) Hipertextualidade; f) Polifonia.

Relativo à Metamorfose, Ramal pontua que através deste se caracteriza a natureza de constantes mudanças pelas quais a estrutura curricular pode passar no processo de ensinoaprendizagem, atribuindo estas transformações com base nas "[...] necessidades, o momento, o contexto e os interesses dos alunos e os objetivos educacionais de seus educadores". (2002, p. 185). Já no que se refere ao princípio da Mobilidade dos Centros, pode-se afirmar que este vem complementar a caracterização fluída e mutável do currículo em rede, visto que reafirma a condição de que não possível pré-determinar quais serão as áreas do conhecimento a serem abordadas durante o desenvolvimento de um projeto de aprendizagem. Nestes termos, Ramal 
indica que, nesta visão rizomática sobre o currículo não existem "[...] limites nem partes estabelecidas antecipadamente por uma única instância, mas sim pontos e conteúdos de uma imensa malha heterogênea que podem ser ativados ou não conforme a pertinência e o percurso da pesquisa". (2002, p. 185)

Os princípios da Interconexão e Exterioridade podem ser considerados conjuntamente para uma explicação do caráter fractal e aberto desta visão curricular. Pelo princípio da Interconexão é possível apreender a organização multilinear e fractal do currículo em rede, ou seja, da característica de que cada nó da malha curricular (conteúdos, idéias, conceitos, instituições, pensadores) pode conter em seu interior uma nova rede que pode integrar-se ao contexto complexo de conhecimentos circundantes a um determinado projeto de aprendizagem. (Ibidem, p. 185-186). Ligado a esta questão, tem-se o princípio da Exterioridade, que propõe o diálogo permanente dos nós da rede com o exterior, ou seja, com elementos que não fazem parte da rede curricular em um determinado momento, mas que devido ao contexto e às condições em que ela opera pode promover processos de reorganização completa desta malha para atingir novos objetivos.

Por fim, a partir do princípio da Polifonia, o currículo em rede se apropria da idéia da interdisciplinaridade, da pluralidade de visões sobre o mundo, da diversidade dos saberes dos nós da rede de ensino-aprendizagem, e, principalmente, a noção de respeito e integração de todas as vozes em processos de dialogo e negociação.

\section{Considerações Provisórias}

Através da realização de um processo de reflexão visando o encontro de pontos de união entre os Projetos de Ensino-Aprendizagem e as Tecnologias Digitais de Rede, buscouse neste artigo a construção de um referencial teórico que pudesse abarcar o delineamento de conceitos e características destas tecnologias que tem a capacidade de serem potencializadores dos pressupostos educacionais da re-significação proposta para o uso dos Projetos na Educação. Ao efetivar este processo de imbricação através de três pontos-chaves - os processos de ensino-aprendizagem, os papeis/relação de professores e alunos, e a constituição do currículo escolar -, procurou-se demonstrar que é possível delimitar uma proposta de sistema didático por Projetos que conflui, conjuntamente com os conceitos derivados da temática das Tecnologias Digitais de Rede, para um possível ponto de convergência entre duas áreas do conhecimento humano: Informática e Educação.

Concluindo, ressalta-se a importância que o trabalho teórico interdisciplinar possui para a efetivação de propostas de pesquisa que possuem como objeto de estudo o fenômeno educativo, pontuando que a compreensão deste fenômeno perpassa, invariavelmente, por uma visão holística, complexa, baseada na integração e comunicação de diversas áreas do conhecimento humano.

\footnotetext{
${ }^{1}$ KANT, Immanuel. Sobre a Pedagogia. 3. ed. Piracicaba: Unimep, 2002.

2 Uma experiência interessante a ser verificada sobre este assunto é a da Escola da Ponte de Portugal (CANÁRIO; MATTOS; TRINDADE, 2004).

${ }^{3}$ Este fato pode ser empiricamente verificado: efetuando uma pesquisa no site de busca Google no dia 15/02/09, pelo termo "Tecnologia da Informação e Comunicação", encontrou-se aproximadamente 7.120.000 resultados que relatam o uso deste termo em alguma página Web. Muitos destes resultados, se pesquisados a fundo, mostraram um campo de significação extremamente amplo para este termo, visando designar as tecnologias que unem a informática e as telecomunicações.

4 Um exemplo de uso deste significado nos termos TIC/NTIC pode ser encontrado na Wikipédia: http://pt.wikipedia.org/wiki/Novas_tecnologias_de_informa\%C3\%A7\%C3\%A3o_e_comunica\%C3\%A7\%C3\% A3o
} 


\section{Referências Bibliográficas}

CASTELLS, Manuel. A sociedade em rede. 9.ed. São Paulo: Paz e Terra, 1999.

DEWEY, John. Democracia e educação: introdução à filosofia da educação. 3.ed. São Paulo: Nacional, 1959.

FAGUNDES, Léa da Cruz; SATO, Luciane Sayuri; MAÇADA, Débora Laurino. Aprendizes do futuro: as inovações começaram! Coleção Informática para a mudança na Educação. Brasília: MEC/SEED/ProInfo, 1999.

HERNÁNDEZ, Fernando. Transgressão e mudança na educação: os projetos de trabalho. Porto Alegre: ArtMed, 1998.

LEMOS, André. Cibercultura: alguns pontos para compreender a nossa época. In: LEMOS, André; CUNHA, Paulo (Org.). Olhares sobre a cibercultura. Porto Alegre: Sulina, 2003. p. 11-23.

LÉVY, Pierre. A inteligência coletiva: por uma antropologia do ciberespaço. 4.ed. São Paulo: Loyola, 2003.

LÉVY, Pierre. As tecnologias da inteligência: o futuro do pensamento na era da informática. Rio de Janeiro: Editora 34, 1993.

LÉVY, Pierre. Cibercultura. São Paulo: Editora 34, 1999.

LOURENÇO FILHO, Manuel B. Introdução ao estudo da escola nova: bases, sistemas e diretrizes da pedagogia contemporânea. 12. ed. São Paulo: Melhoramentos, 1978.

LUCKESI, Cipriano. Avaliação da aprendizagem escolar. 17. ed. São Paulo: Cortez, 2005.

OLIVEIRA, Marta K. de. Vygotsky, aprendizado e desenvolvimento: um processo sóciohistórico. São Paulo: Scipione, 1997.

PINO, Angel. Cultura e desenvolvimento humano. Lev Semenovich Vygotsky: uma educação dialética, Rio de Janeiro, n. 2, p. 14-21, 2005. Coleção Memória da Pedagogia.

RAMAL, Andrea Cecília. Educação na cibercultura: hipertextualidade, leitura, escrita e aprendizagem. Porto Alegre: ARTMED, 2002.

REGO, Teresa C. Ensino e constituição do sujeito. Lev Semenovich Vygotsky: uma educação dialética, Rio de Janeiro, n. 2, p. 58-67, 2005. Coleção Memória da Pedagogia.

SANTAELLA, Lúcia. Navegar no ciberespaço: o perfil cognitivo do leitor imersivo. São Paulo: Paulus, 2004.

SANTOMÉ, Jurjo Torres. Globalização e interdisciplinaridade: o currículo integrado. Porto Alegre: Artes Médicas, 1998.

SERPA, Felippe. Rascunho digital: diálogos com Felippe Serpa. Salvador: Edufba, 2004.

SILVA, Marco. Sala de aula interativa. 3.ed. Rio de Janeiro: Quartet, 2002.

SILVA, Marco; CLARO, Tatiana; A docência online e a pedagogia da transmissão. Boletim Técnico do Senac, São Paulo, v. 33, n.2, maio/ago. 2007. Disponível em: $<$ http://www.senac.br/BTS/332/artigo-7.pdf>. Acesso em: 21 out. 2008.

SMOLKA, Ana Luiza B.; DE LAPLANE, Adriana Lia F. Processos de cultura e internalização. Lev Semenovich Vygotsky: uma educação dialética, Rio de Janeiro, n. 2, p. 76-83, 2005. Coleção Memória da Pedagogia.

TEIXEIRA, Adriano Canabarro. Formação docente e inclusão digital: a análise do processo de emersão tecnológica de professores. 2005. Tese (Doutorado em Informática na Educação) - Universidade Federal do Rio Grande do Sul, Porto Alegre, 2005.

VYGOTSKY, Lev S. A formação social da mente: o desenvolvimento dos processos psicológicos superiores. 6. ed. São Paulo: Martins Fontes, 1998.

. Pensamento e linguagem. 3.ed. São Paulo: Martins Fontes, 1991. 